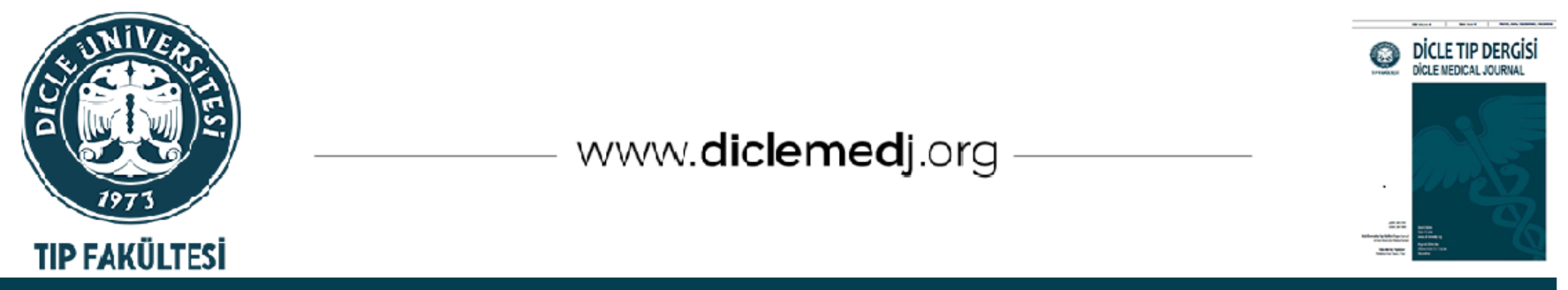

Original Article / Özgün Araştırma

\title{
Results of Minimally Invasive Methods in the Treatment of Liver Hydatid Cyst
}

\author{
Erkan Dalbaşı ${ }^{\text {i }}$, Abidin Tüzün ${ }^{2}$ \\ 1 Memorial Hospital General Surgery Clinic, Diyarbakır, Turkey \\ 2 Gazi Yasargil Training and Research Hospital General Surgery Clinic, Diyarbakır, Turkey
}

Received: 04.08.2021; Revised: 24.10.2021; Accepted: 26.10.2021

\begin{abstract}
Objective: The most common cause of hydatid cyst disease is Echinococcus granulosus. Nowadays, minimally invasive methods such as laparoscopy used in the treatment of hepatic hydatid cyst (HHC). In this study, it is aimed to share the clinical, surgical and postoperative data of patients who underwent laparoscopic surgery with a diagnosis of HHC in our clinic.

Methods: Data of 105 patients who underwent laparoscopic surgery for HHC between January 2011 and January 2020 were retrospectively analyzed. Patients who were diagnosed with $\mathrm{HHC}$ by clinical, indirect hemagglutination test, upper abdominal ultrasonography (USG) and upper abdominal tomography were included in the study. All patients received $10 \mathrm{mg} / \mathrm{kg}$ / day albendazole therapy for a total of six weeks, two weeks preoperatively and four weeks postoperatively. Demographic information, clinical characteristics, and the incidence and percentage of complications were analyzed by simple manual calculation.
\end{abstract}

Results: 64 (60.95\%) of 105 patients who underwent laparoscopic surgery were male and 41 (39.05\%) were female. The mean age was $40.6 \pm 11.7$ years (18-65 age range). The mean cyst diameter was $8.4 \mathrm{~cm}$ in size (minimum: $6 \mathrm{~cm}$, maximum: $16 \mathrm{~cm}$ ). The mean operation time was $55 \pm 11.45$ minutes (Range: 42 to 70 minute). The mean hospitalization period of the patients was 3.7 days (Range 2 to 7). No recurrence was observed in the 18-month follow-up of the patients.

Conclusions: HHC is a common disease in our country, and we think that laparoscopic approach is an effective surgical treatment option in suitable patients and in experienced centers.

Key words: hydatid cyst, liver, laparoscopy, minimally invasive

DOI: 10.5798/dicletip.1037579

Correspondence / Yazışma Adresi: Erkan Dalbaşı, Memorial Hospital General Surgery Clinic, Diyarbakır, Turkey e-mail: erkandalbasi9@gmail.com 


\section{Karaciğer Kist Hidatik Tedavisinde Minimal invaziv Yöntem Sonuçlarımız}

Öz

Amaç: Karaciğer kist hidatik (KKH) özellikle tarım ve hayvancılığın yaygın olduğu bölgelerde endemik olarak görülen bir hastalıktır. En sık etkeni küçük bir sestod olan Echinococcus granulosusdur. KKH tedavisinde minimal invaziv yöntemler günümüzde daha yaygın kullanılmaktadır. Bu çalışmada kliniğimizde KKH nedeniyle laparoskopik cerrahi uygulanan hastaların klinik, cerrahi ve ameliyat sonrası verilerinin paylaşılması amaçlanmıştır.

Yöntemler: Ocak 2011 ve Ocak 2020 tarihleri arasında KKH nedeniyle laparoskopik cerrahi uygulanan 105 hastanın verileri retrospektif olarak incelendi. Hastalar yaş, cinsiyet, kistin yerleşim yeri, sayısı ve boyutu, başvuru şikayeti, hastanede kalış süresi, nüks, komplikasyonlar ve komplikasyonlara yönelik uygulanan tedavi yöntemleri açısından incelendi. Çalışmaya klinik, indirek hemaglütinasyon testi, üst batın ultrasonografisi (USG) ve üst batın tomografisi ile KKH tanısı konulan hastalar dahil edildi. Tüm hastalara, ameliyat öncesi iki hafta ve ameliyat sonrası dört hafta olmak üzere toplam altı hafta $10 \mathrm{mg} / \mathrm{kg} /$ gün albendazol tedavisi verildi. Tüm hastalara laparoskopik olarak drenaj, perikistektomi ve omentoplasti uygulandı. Hastalar taburcu edildikten sonra 1,6,12 ve 18. aylarda üst batın usg ile nüks açısından değerlendirildi. Demografik bilgiler, klinik özellikler ve komplikasyonların insidansı ve yüzdesi basit manuel hesaplama ile analiz edildi.

Bulgular: Laparoskopik cerrahi uygulanan 105 hastanın $64(\% 60,95)$ tanesi erkek, $41(\% 39,05)$ tanesi kadındı. Ortalama yaş 40,6 $\pm 11,7$ yıldı (18-65 yaş aralığı). Hastaların $70(\% 66,66)$ tanesi karın ağrısı, $5(\% 4,76)$ tanesi sarılık, $15(\% 14.28)$ tanesi bulantı, şişkinlik gibi dispeptik yakınmalar, $5(\% 4,76)$ tanesi ateş ve karın duvarında şişlik şikayetleri ile başvurmuşlardı. $10(\% 9,52)$ hastaya ise insidental olarak tanı konulmuştur. Ortalama kist çapı 8,4 cm boyutunda idi (minimum: $6 \mathrm{~cm}$, maksimum: $16 \mathrm{~cm}$ ). Ortalama ameliyat süresi 55 $\pm 11,5$ dakika idi (minimum:42 maksimum: 70 dakika). Ameliyat esnasında $10(\% 9,52)$ hastada kist poşu içerisinde safra kanalı tespit edildi ve bu safra kanalları laparoskopik olarak 3/0 ipek sutur ile kapatıldı. Trokar giriş yeri enfeksiyonu görülmedi. Hastaların 18 aylık takiplerinde nüx görülmedi.

Sonuç: KKH'in cerrahi tedavisinde uygun hastalarda ve tecrübeli merkezlerde laparoskopik yaklaşımın etkin bir cerrahi tedavi seçeneği olduğunu düşünmekteyiz.

Anahtar kelimeler: kist hidatik, karaciğer, laparoskopi, minimal invaziv.

\section{INTRODUCTION}

Hydatid cyst disease, which is a zoonotic infestation, is a disease that has been known since the 17 th century and is endemic in regions where agriculture and animal husbandry are common today. The most common cause of hydatid cyst disease, also known as echinococcosis, is Echinococcus granulosus (E.G), a small cestode. E. multilocularis and E. alveolaris are less common. Although the disease is seen at all ages, it is more common in young men. While its incidence in the world is around $200 / 100000$, it increases to $10 \%$ in our country, especially in the eastern and southeastern regions. Today, despite early diagnosis methods and advanced surgical techniques, it can cause around $10 \%$ morbidity and approximately $1 \%$ mortality depending on the location of the cyst. Canines are the main host for this parasite. The eggs laid by the parasites in the small intestine are excreted with feces. After the water and food contaminated with eggs are taken by intermediate hosts. The most common organ in humans is the liver, around $75 \%$. In the liver, they most frequently settle in the right lobe. The most commonly involved organs after the liver are the lungs and spleen ${ }^{1,2}$. Surgical treatment has long been a curative option in the treatment of hepatic hydatid cyst (HHC). Nowadays, minimally invasive methods such as laparoscopy and percutaneous drainage are also used in the treatment of HHC. Percutaneous drainage, partial hepatectomy, total or partial cystectomy and drainage treatment alternatives of HHC. Treatment options should be 
determined according to the morphology, size, number and location of the cysts ${ }^{3}$.

In this study, we aimed to share the demographic information of patients who were diagnosed with HHC and treated with laparoscopic method, the reasons for application, the location and size of the cysts, the complication and recurrence rates.

\section{METHOD}

Approval for this study was obtained from Gazi Yaşargil Training and Research Hospital ethics committee with protocol number 641 and date 15.01.2021. Data of 105 patients who underwent laparoscopic surgery for HHC between January 2011 and January 2020 were retrospectively analyzed. The patients were analyzed retrospectively in terms of age, gender, location, number and size of the cyst, complaints at presentation, length of hospital stay, recurrence, complications, and treatment methods for complications. Patients who were diagnosed with HHC by clinical, indirect hemagglutination test, upper abdominal ultrasonography (USG) and upper abdominal tomography were included in the study. Gharbi classification was made with imaging methods. The Gharbi classification is shown in table $1^{4}$. Patients with Gharbi type 1 and type 5, previous abdominal surgery, recurrent hydatid cysts, multi-organ involvement, albendazole allergy and those who could not receive general anesthesia were excluded from the study. All patients received $10 \mathrm{mg} / \mathrm{kg} /$ day albendazole therapy for a total of six weeks, two weeks preoperatively and four weeks postoperatively. Endoscopic retrograde cholangio pancreatography (ERCP) sphincterectomy was performed in patients with preoperative direct hyperbilirubinemia.
Table I: Classification by Gharbi et al for hydatid cysts.

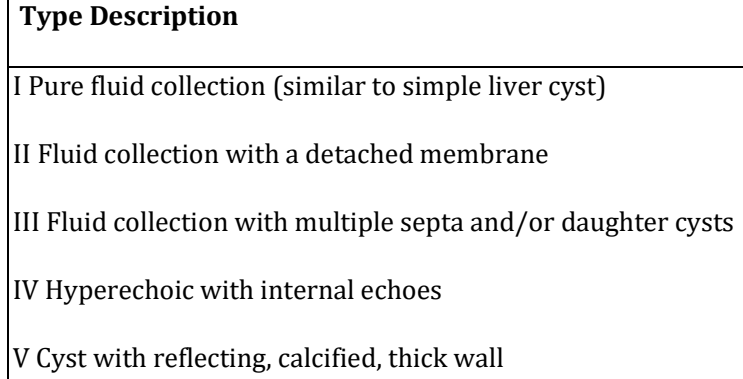

General anesthesia was given to all patients. After the antisepsis was provided, pneumoperitoneum was created with $\mathrm{CO} 2$ gas at a rate of $14 \mathrm{mmhg}$ with a $10 \mathrm{~mm}$ trocar placed over the umbilicus in a neutral position. The inside of the abdomen was explored with a 10 $\mathrm{mm} 30$ degree telescope from this trocar. A total of 4 ports were used. Patients were positioned according to the location of the cyst. Sponges soaked with hypertonic saline were placed around the liver to prevent the contamination of the cyst contents into the abdomen. Minimal cystotomy was performed with the help of a hook passed through a five trocar at the point where the hydatid cyst pouch was the most prominent. Cyst fluid and doughter vesicles were aspirated from the cystotomy area with the help of a large-diameter aspiratör. After the pressure in the pouch was reduced, pericyst resection was performed with the help of an energy-based vessel sealing device. The germinative membrane was removed with an endobag. The pouch content was filled with hypertonic saline to inactivate possible scoleks in the cavity. Then, the camera was inserted into the cyst pouch and bile fistula, bleeding, and remaining girl vesicles were checked. After the cyst content was cleaned, the omentum was placed in the cyst. Then, sponges around the liver were taken into the endobag and removed. A drainage tube was taken into the abdomen and placed in the right hypochondrium. Drain 
content was clean and the drain was withdrawn when the daily flow rate fell below $50 \mathrm{cc}$. Patients whose biliary drainage continued for more than 3 days or whose flow rate was 500cc or more per day for three days were directed to the ERCP procedure. The patients were evaluated for recurrence with the upper abdominal USG at 1,6,12 and 18 months after discharge. Demographic information, clinical characteristics, and the incidence and percentage of complications were analyzed by simple manual calculation.

\section{RESULTS}

$64(60.95 \%)$ of 105 patients who underwent laparoscopic surgery were male and 41 (39.05\%) were female. The mean age was 40.6 \pm 11.7 years (18-65 age range). $70(66,66 \%)$ of the patients presented with abdominal pain, 5 (4.76\%) with jaundice, 15 (14.28\%) with dyspeptic complaints such as nausea and bloating, 5 (4.76\%) with fever and lump in the abdominal wall. $10(9.52 \%)$ patients were diagnosed incidentally. The clinical presentations of the patients are summarized in table $2.72(68.57 \%)$ of the patients had a single cyst, $28(26.66 \%)$ patients had two cysts, and five patients had $3(2.85 \%)$ cysts. A total of 137 hydatid cyst pouches were intervened. 92 $(67.15 \%)$ of these cysts were located in the right lobe, $31(22.62 \%)$ in the left lobe, and 14 $(10.23 \%)$ in both lobes. The number of cysts and their localizations are summarized in table 3 . The mean cyst diameter was $8.4 \mathrm{~cm}$ in size (minimum: $6 \mathrm{~cm}$, maximum: $16 \mathrm{~cm}$ ). The mean operation time was $55 \pm 11.5$ minutes (Range: 42 to 70 minutes). During the operation, bile duct was detected in the cyst pouch in 10 (9.52\%) patients and these bile ducts were closed laparoscopically with $3 / 0$ silk suture. There was no bleeding that could be morbid in any patient. ERCP was used in 5 (4.75\%) patients after surgery due to the high flow rate of bile drainage in the drain. Biliary drainage decreased after ERCP and fistula closed without additional intervention. Drain retention was on average 4.2 days (range 3 to 10 days). The mean hospitalization period of the patients was 3.7 days (range 2 to 7 days). Trocar insertion site infection was not seen. No recurrence was observed in the 18-month follow-up of the patients. Hernia was observed at the umbilical trocar site in $8(7.61 \%)$ patients. All of the patients with hernias were women and their body mass index was over thirty.

Tablo II: Clinical presentation of patient with hydatid cyst of liver.

\begin{tabular}{|l|}
\hline $\begin{array}{l}\text { Clinical features Number of patients Percentage } \\
\text { (\%) }\end{array}$ \\
\hline Abdominal pain 7066.66 \\
Dyspepsia 1514.28 \\
Incidental 109.52 \\
Icter 54.76 \\
Fever, abdominal lump 54.76 \\
\hline
\end{tabular}

Table III: Number and location of cyst.

Number of Cyst Number of Patients Percentage

(\%)

Single 7268.57

Two 2826.66

Three 32.85

Location Number of Cyst Percentage (\%)

Right lobe 9267.15

Left lobe 3122.62

Both lobe 1410.23

\section{DISCUSSION}

Today, technological developments are advancing in every field.Parallel to these advances in technology, minimally invasive interventions have been widely used in the diagnosis and treatment of diseases ${ }^{5}$. With these developments, minimally invasive treatment options are successfully applied in experienced centers in the treatment of HHC. Percutaneous aspiration, injection, re- 
aspiration (PAIR) method is one of these options. PAIR method was first defined by Müller et.al. The PAIR method is particularly effective in the treatment of Gharby Type 1, type 2 and some type 3 hydatid cysts whose solid component can be aspirated 6 . The World Health Organization Ekinococcosis Working Group reported a multicenter study involving the results of 765 patients who underwent PAIR. In this study, the complication rate was found to be $14.7 \%$, and the recurrence rate was $1.57 \%{ }^{7}$. In our center, we refer patients diagnosed with Gharby type 1 and type 2 HHC to the relevant clinic for PAIR application. PAIR should be recommended for patients at high risk of anesthesia, pregnant women, and patients with multiple or disseminated cysts. Akhan et al. compared the long-term results of the PAIR and catheterization method and found the major complication rate of patients undergoing PAIR to be $2.94 \%$. This ratio was found to be $36.94 \%$ in the catheterization group. They found the PAIR method successful in the treatment of liver CE1 and CE3a cysts, due to lower rates of major complications and hospital stay ${ }^{8}$.

Another minimally invasive method of treatment for HHC is laparoscopic surgery. This method was first described by Kathuda et al. It was published in $1992^{9}$. Later, the laparoscopic approach in the treatment of HHC was combined with different surgical approaches such as partial or total cystectomy, marsupialization, or hepatectomy. The appropriate method should be preferred according to the number and location of the cyst and the surgeon's experience ${ }^{5}$. Laparoscopic drainage, partial pericystectomy, and omentoplasty are conservative techniques and are suitable for all HHC. These procedures are technically easier and have a lower morbidity. It requires the use of drug therapy for girl vesicles or small germinative membrane residues that may remain in the cyst pouch ${ }^{10}$. Laparoscopic pericystectomy and hepatectomy methods are radical surgeries. The advantages of radical laparoscopic methods are reduced recurrence, no need for postoperative protoscocidal drugs, and better management of cavity-related complications such as cystobiliary fistula. However, morbidity is more common in radical methods. Therefore, radical interventions for a benign disease should not be applied unless there is a definite indication ${ }^{11,12}$. We performed drainage, pericystectomy and omentoplasty in our study. Albendazole treatment was given to the patients before and after surgery. We found no major complications, mortality or recurrence in follow-up.

The opening of the biliary ducts into the cyst can be seen in large cysts, especially $7 \mathrm{~cm}$ and above. It has been stated in the literature that approximately $6 \%$ of bile fistula may occur ${ }^{13}$. The presence of bile ducts should be evaluated in detail in the operation. In this study, the rate of postoperative biliary fistula was found to be $4.75 \%$ and was treated with ERCP. It has been shown that albendazole treatment before the operation reduces the pressure inside the cyst, and sponges washed with scolocidal agent should be placed around the cyst to protect the tissues around the abdomen from contamination $^{14}$. In our study, preoperative and postoperative albendazole treatment was given to all patients. Protective measures have been taken around the liver to prevent contamination during surgery.

Sokouti et al. reviewed six studies involving 1028 patients in a systematic analysis. They compared the results of open and laparoscopic surgery for HHC treatment. While the complication rates in patients treated with laparoscopic method are between $8-25 \%$ in the literature, this rate is around $12-65 \%$ in open surgery. They stated that while mortality was close to zero in laparoscopic method, it could increase up to $6 \%$ in open surgery ${ }^{15,16}$. Mortality in our study was zero. The complication rate 
was approximately $5 \%$ and was consistent with the literature.

Tuxun et al. performed laparoscopic surgery on 60 of 353 patients diagnosed with HHC and open surgery to others. They found that the operating time and hospital stay were significantly lower in the laparoscopic group. General morbidity was $13.3 \%$ in the laparoscopic group and $19.6 \%$ in the open group. During the 48-month follow-up, recurrence was observed in one patient in the laparoscopic group and in five patients who underwent open surgery ${ }^{17}$. Pandey et al. retrospectively analyzed 30 patients diagnosed with abdominal hydatid cyst. They found the rate of cystobiliary relationship 3\%. This rate was found to be $9.52 \%$ in our study. Transient bile leakage was observed in two postoperative cases (7\%), and this rate was found to be $4.75 \%$ in our study ${ }^{18}$. Busic et al. compared the results of laparoscopic and open surgery for CHD and stated that the laparoscopic approach was more advantageous ${ }^{19}$. All these literature data are compatible with our study.

Bedioui et al. retrospectively investigated predictive factors that may cause morbidity after surgical treatment in HHC patients. They stated that a cyst diameter of $9 \mathrm{~cm}$ or more, being located in the liver dome, and being associated with the biliary system were factors that increased morbidity ${ }^{20}$. Manterola et al. In their study, age, history of previous CHD surgery, location of the cyst, presence of bile communication and evolutionary complications of the cyst were stated as risk factors in the treatment of HHC. They stated that radical surgical techniques were protective ${ }^{21}$.

Goumas et al. conducted a study showing the efficacy of endoscopic methods in biliary system complications in patients with HHC. They evaluated 15 patients with biliary system symptoms after HHC surgery with ERCP. Biliary tract disorders due to hydatidosis were detected in nine patients and their treatment was provided with ERCP22. Sharma et al. evaluated patients who developed cystobiliary fistula in 28 out of 120 patients who were operated for CHD within 10 years. They treated all patients with the ERCP method. In an average of eleven days after ERCP, the fistula was closed and complete recovery was achieved $^{23}$. In our study, early bile fistulas in five patients were treated with ERCP. Sphincterectomy, nasobiliary drainage, and stenting to the biliary tract are minimally invasive treatment options that can be applied with ERCP.

Although hydatid cyst is still an important public health problem in the world, it is a disease that can be prevented with simple measures. Breaking the biological life cycle of the parasite is very important in the control of the disease. Dogs breeding is very important in regions where agriculture and animal husbandry are common. We must make sure that drinking water and food are clean. Slaughterhouses and slaughtering should be done under control ${ }^{24}$.

\section{CONCLUSIONS}

Nowadays, minimally invasive procedures are preferred for the surgical treatment of diseases and for the correction of possible complications of these treatments. HHC is a common disease in our country, and we think that laparoscopic approach is an effective surgical treatment option in suitable patients and in experienced centers.

Ethics Committee Approval: Approval for this study was obtained from Gazi Yaşargil Training and Research Hospital ethics committee with protocol number 641 and date 15.01.2021.

Declaration of Conflicting Interests: The authors declare that they have no conflict of interest.

Financial Disclosure: No financial support was received. 


\section{REFERENCES}

1. Wen H, Vuitton L, Tuxun T, et. al. Echinococcosis: Advances in the 21st Century. Clin Microbiol Rev. $2019 ; 32$.

2. Çaycı M, Tihan D. Karaciğer Kist Hidatik Tedavisinde Güncel Yaklaşım. Uludağ Üniversitesi Tıp Fakültesi Dergisi 2016;42: 53-9.

3. Shrestha S.K, Thapa P.B, Maharjan D.K, Tamang T.Y. Laparoscopic Approach for Management of Hydatid Cyst of Liver. J Nepal Health Res Counc 2017; 15: 6770.

4. Mirabile E, Solomon N, Fields PJ, Macpherson CNL. Progress towards international adoption of the World Health Organization ultrasound classification of cystic echinococcosis. Acta Trop. 2019; 189: 6-9.

5. Vardakostas D, Damaskos C, Garmpis N, et.al. Minimally invasive management of hepatic cysts: indications and complications. European Review for Medical and Pharmacological Sciences. 2018; 22: 1387-96.

6. Mueller P.R, Dawson S.L, Ferrucci J.T, Nardi G.L. Hepatic echinococcal cyst: successful percutaneous drainage. Radiology. 1985; 155: 627-8.

7. Vuitton D, Meslin F, Mac Pherson C, Brunetti E, Filice C. World Health Organization Informal Working Group on echinococcosis. PAIR: an option for the treatment of cystic echinococcosis.2002; Bull World Heal Organ.

8. Akhan 0, Erdoğan E, Ciftci TT, et al. Comparison of the Long-Term Results of Puncture, Aspiration, Injection and Re-aspiration (PAIR) and Catheterization Techniques for the Percutaneous Treatment of CE1 and CE3a Liver Hydatid Cysts: A Prospective Randomized Trial. Cardiovasc Intervent Radiol. 2020; 43: 1034-40.

9. Katkhouda N, Fabiani P, Benizri E, Mouiel J. Laser resection of a liver hydatid cyst under videolaparoscopy. Br J Surg 1992; 79: 560-1.

10. Kayaalp C. Hydatid cyst of the liver. Surg Liver, Biliary Tract, Pancreas 2007; 4: 952-70.

11. Busić Z, Lemac D, Stipancić I, et al. Surgical treatment of liver echinococcosis--the role of laparoscopy. Acta Chir Belg 2006; 106: 688-91.

12. Avgerinos E.D, Pavlakis E, Stathoulopoulos A, et al. Clinical presentations and surgical management of liver hydatidosis: our 20 year experience. HPB (Oxford) 2006; 8: 189-93.
13. Tuxun T, Zhang JH, Zhao JM, et al. World review of laparoscopic treatment of liver cystic echinococcosis 914 patients. Int J Infect Dis. 2014; 24: 43-50.

14. Aktan A0, Yalin R. Preoperative albendazole treatment for liver hydatid disease decreases the viability of the cyst. Eur J Gastroenterol Hepatol. 1996; 8: 877-9.

15. Sokouti M, Sadeghi R, Saeid Pashazadeh S, et.al. A systematic review and meta-analysis on the treatment of liver hydatid cyst: Comparing laparoscopic and open surgeries. Arab Journal of Gastroenterology Volume 18, 3: 2017, p: 127-35

16. Zaharie F, Bartos D, Mocan L, et.al. Open or laparoscopic treatment for hydatid disease of the liver? A 10-year single-institution experience. Surgical Endoscopy 2013; 27: 2110-6.

17. Tuxun T, Aji T, Tai Q, et.al. Conventional Versus Laparoscopic Surgery for Hepatic Hydatidosis: a 6Year Single-Center Experience. Journal of Gastrointestinal Surgery 2014; 18: 2 p: 1155-60.

18. Pandey A, Chandra A, Masood S. Abdominal echinococcosis: outcomes of conservative surgery. Transactions of The Royal Society of Tropical Medicine and Hygiene, 2014; 108(5) p:264-68.

19. Busic Z, Cupurdija K, Servis D, et.al. Surgical Treatment of Liver Echinococcosis Open or Laparoscopic Surgery? Coll Antropol 2012: 36: 1363-6.

20. Bedioui H, Bouslama K, Maghrebi H, et.al. Predictive factors of morbidity after surgical treatment of hepatic hydatid cyst. Pan Afr Med J. 2012; 13: 29.

21. Manterola C, Otzen T, Muñoz G, et.al. Surgery for hepatic hidatidosis. Risk factors and variables associated with postoperative morbidity. Overview of the existing evidence. Cir Esp. 2017; 95: 566-76.

22. Goumas K, Poulou A, Dandakis D, et.al. Role of endoscopic intervention in biliary complications of hepatic hydatid cyst disease. Scand J Gastroenterol. 2007; 42: 1113-9.

23. Sharma B.C, Reddy R.S, Garg V. Endoscopic management of hepatic hydatid cyst with biliary communication. Dig Endosc. 2012; 24: 267-70.

24. Sayır F, Çobanoğlu U. Yöremizin Endemik Paraziter Hastalı̆̆ı: Kist Hidatik. Van Tıp Dergisi:2013; 20: 28893. 